\title{
The economics of oil and gas supply in the Former Soviet Union
}

\author{
Roberto F. Aguilera \\ Centre for Research in Energy and Minerals Economics (CREME) Curtin University \\ GPO Box 1987 \\ Perth, Western Australia 6845 Australia \\ Email: r.aguilera@curtin.edu.au \\ Phone: 618-9266-9137
}

\begin{abstract}
Supply costs curves for the Former Soviet Union (FSU) are constructed for conventional petroleum, which is defined as conventional oil, natural gas and natural gas liquids (NGL). The supply figures show how petroleum quantities vary with production costs over time. Five resource quality categories, distinguishable according to production costs, are used in the estimation. The quantities are allocated across the five categories in a fixed proportion in order to generate the supply cost curves. The role of annual productivity gains, i.e. technological progress, to the year 2030 is also included. Results indicate that petroleum in the FSU is abundant and can be produced economically. In addition, production costs are found to decrease further over time as technology advances. With appropriate energy policy, FSU petroleum resources should assist in meeting domestic and international energy demand.
\end{abstract}

Keywords: supply cost curve; conventional oil and gas; Former Soviet Union 


\section{Introduction}

Some energy commentators believe there may be a shortage of commercially viable petroleum in the FSU due to surging global demand combined with inadequate regional supply. Thus, the purpose of this analysis is to addresses the concern by estimating conventional petroleum supply cost curves for the region. The end result is a two-dimensional representation of long run availability versus average total production costs.

Although FSU petroleum is believed to exist in significant quantities (Aguilera, 2011), above ground factors are important determinants in development. Palstev (2010) identifies several drivers of future gas production in the FSU. These include the availability of domestic gas at reasonable prices, the state of world gas production and trade, the structure of future environmental policies, the concerns about nuclear energy, and the rate of development of Asia Pacific gas markets. With regard to oil, Gorst (2010) states that current tax regimes in the region do not provide incentives for producers to invest in necessary infrastructure. Thus, oil production growth is forecasted to decline in the coming years. In addition, the existing major fields of the FSU are considered mature and are already experiencing production profiles in gradual decline. Although this may be offset by new fields in frontier areas, including offshore, significant capital funding and advanced development technologies will be necessary. Governments in the region generally control the resources through national oil and gas companies, though they show increasing interest in developing international partnerships so as to raise capital and acquire technological expertise. The international companies are also keen to secure opportunities in FSU with the purpose of developing the vast resource potential. Therefore, regional petroleum supply 
International Journal of Global Energy Issues. 35 (6): 2012. http://dx.doi.org/10.1504/IJGEl.2012.051730.

Copyright @2012 Inderscience Enterprises Ltd.

could increase greatly if governments provide incentives for establishing long-term partnerships with private firms in and outside the FSU.

In spite of the very important global, political and historical context of petroleum in the FSU, the present study merely aims to assess the current and possible future production costs of conventional petroleum resources in the FSU along with the estimated quantities. The volumes presented in Aguilera (2011) employ a simple mathematical method that analyses the relationship between the sizes versus numbers (rank) of FSU geological provinces. Although complex geological methods - such as those undertaken by the United States Geological Survey (e.g. USGS, 2000) and the German Federal Institute for Geosciences and Natural Resources (e.g. BGR, 2009) - probably result in the most authoritative estimates, the simpler size distribution models serve as a useful complement and tend to give converging results. Some of the other methods commonly used to assess petroleum supply are life cycle models (e.g. Hubbert's logistic curves), rate of effort models, subjective probability models, discovery process models, econometric models, decision analysis and portfolio management. With regard to size distribution analysis, Adelman et al. state "the concept of deposit size distribution is an essential component of models of petroleum supply designed to reflect industry behavior in a logical way" (1983, p. 90). Examples of oil and gas supply techniques and reviews include Eckbo et al. (1978), Krichine (2002), Lynch (2005), Sorrell et al. (2010), and Walls (2004).

Although this paper presents costs and quantities, it does not address the rate at which commercial production may come online. Various factors will influence that rate, including the incentives or disincentives for foreign private producers. For instance, Radetzki (2012) points out 
that the cost to produce oil from an undeveloped field in Russia is about 12 USD per barrel of oil equivalent (BOE) plus an additional $6 \mathrm{USD} / \mathrm{BOE}$ for transportation. Moreover, a national mineral tax imposes another 14 USD/BOE, while the tax to export from Russia is USD 40/BOE. It is apparent that the economics become far less viable with these additions, so it is important to note that this study does not account for taxes and royalties.

\section{Methods and data}

The methodology for developing the supply cost curves involves distributing quantities across five categories based on resource quality. The first category is similar to what is traditionally known as proved reserves. The second category represents probable reserves, the third possible, the fourth enhanced recovery, and the fifth deep offshore. Each category is then assigned a lower and upper bound of production costs, resulting in a supply cost curve based on current technology. Additional supply cost curves assuming technological performance in 2030 are also constructed. Productivity gains at rates between $0.5 \%$ and $1.5 \%$ per year are used to project the 2030 production costs. Observed historical average rates have been around 1\% (Rogner, 1998).

Oil, gas and NGL future volumes, which are inputs into the supply cost curves, are estimated with a previously defined Variable Shape Distribution (VSD) model (Aguilera, 2006, 2011), discussed briefly in the next section. Data for this study comes from various sources. The VSD-calculated oil, gas and NGL volumes are taken from Aguilera (2011), which in turn uses USGS (2000) data as a starting point. Although the USGS accounts for uncertainty by estimating fractiles (F95, 
F50, F5, and the mean), they publish the mean estimates as their main findings. As such, Aguilera (2011) uses the mean estimates provided by the USGS as inputs to the VSD model. Production statistics, from British Petroleum (2011), are also used to estimate volumes in 2030. Production costs are based on Aguilera et al. (2009), while the methodology for the supply curve construction is similar to Rogner (1998) and Tilton and Skinner (1987). The latter proposed a cumulative supply curve, which shows how the total stock or cumulative supply of petroleum varies with production costs over time. Hence, it summarizes the extraction that could be ultimately realized, though there are no exclusions made for any political, regulatory, or social reasons.

\section{VSD model}

The VSD model calculates the endowment volumes in FSU provinces that have not previously been assessed. The VSD is a statistical method known as size distribution. This type of analysis has historically been successful in complementing geological techniques used to estimate resources in previously unassessed areas. It was validated in Aguilera (2011) by comparing VSD-calculated and actual FSU endowment volumes published by the USGS (2000) study. The plots in Figure 1 show the number (rank) versus size of geological provinces estimated by USGS (2000) and Aguilera (2011). According to the USGS, endowment refers to the sum of known volumes (cumulative production plus remaining reserves) and undiscovered volumes. The oil, gas and NGL endowments represented by the diamond points in each plot of Figure 1 
correspond to provinces assessed by USGS (2000): 18 provinces for oil and NGL and 31 provinces for gas. These USGS-estimated endowments compare well with those calculated by the VSD model (represented by the thick, solid continuous curves of Figure 1). The coefficients of determination ( $\left.\mathrm{R}_{2}\right)$ range from 0.98 to 0.99 . Note that these volumes do not include heavy oil, oil sands, oil shale, tight gas sands, shale gas, coalbed methane, gas hydrates, and offshore provinces with water depths greater than 2000 meters in some cases and 4000 meters in others. In total, the USGS recognizes 141 provinces in the FSU region. Thus, the volumes in 123 oil and NGL provinces and 110 gas provinces were not presented, probably because they were not expected to be exploited within the adopted 30-year time horizon. As stated by the USGS (2000, p. AR-3), "assessed areas were those judged to be significant on a world scale in terms of known petroleum volumes, geologic potential for new petroleum discoveries, and political or societal importance." Furthermore, many of the unassessed provinces are in remote areas where petroleum may exist but due to location and other factors are likely to be high-cost and so presumed by the USGS to be of little commercial interest over its 30-year timeframe. Nevertheless, of the eight world regions assessed by USGS (2000), the FSU ranks first in terms of natural gas endowment and second for oil endowment (behind the Middle East and North Africa region).

The VSD model is then used to estimate the oil, gas and NGL volumes of the 141 provinces recognized by the USGS to exist in FSU. The square points in Figure 1, generated by the VSD model, correspond to 141 provinces. The thin outer curves incorporate the effect of reserve growth, which increase the quantities significantly. For more on reserve growth and its application, refer to Verma (2000) and Aguilera (2011).

Figure 2 is a map showing the FSU with boundaries between geological provinces. The provinces shaded with horizontal stripes represent those assessed previously by the USGS. Although the 
Soviet Union no longer exists, FSU is an area defined by the USGS in their regional disaggregation of the world for the purpose of geological evaluation. As seen in Figure 2, most of the previously assessed provinces are located in the western and central areas of FSU. Tables 1 to 3 provide the province names, codes, and quantities for conventional oil, gas, and NGL. Although the Caspian region is forecasted to experience significant oil production growth in the coming decades, the vast majority of the oil endowment is located in Russia. By 2035, the International Energy Agency (2011) indicates there may be an important shift to higher cost areas in Eastern Siberia, the Arctic, and the Caspian. Other important countries in terms of current and prospective oil quantities include Kazakhstan, and to a lesser extent Azerbaijan, Turkmenistan, and Uzbekistan. As for gas production, the IEA reports that the Yamal Peninsula could become the new anchor for FSU gas, alongside production from the Barents Sea and Eastern Siberia. Outside of Russia, the most significant natural gas countries include Turkmenistan, and to a lesser extent Kazakhstan, Uzbekistan, Azerbaijan, and Ukraine. 
International Journal of Global Energy Issues. 35 (6): 2012. http://dx.doi.org/10.1504/IJGEl.2012.051730.

Copyright @2012 Inderscience Enterprises Ltd.

Figure 1 VSD estimates for 141 FSU provinces, including unassessed provinces and reserve growth (Aguilera, 2011)

11010010000.010.101.0010.00100.001000.00Cumulative Number of ProvincesSize of Provinces $($ BBOE)USGS $(2000)$ data for 18 provinces $=380$ BBOEVSD for 18 provinces $=379$ BBOE $(\mathrm{R} 2=$ $0.99)$ VSD for 141 provinces $=556$ BBOEVSD for 141 provinces plus Reserve Growth $(43 \%)=795$ BBOE11010010000.010.101.0010.00100.001000.0010000.00Cumulative Number of ProvincesSize of Provinces (TCFG)USGS (2000) data for 31 provinces $=3716$ TCFGVSD for 31 provinces $=3714$ TCFG $(R 2=0.99)$ VSD for 141 provinces $=4815$ TCFGVSD for 141 provinces plus Reserve Growth $(56 \%)=7507$ TCFG11010010000110100Cumulative Number of ProvincesSize of Provinces (BBNGL)USGS (2000) data for 18 provinces $=71$ BBNGLVSD for 18 provinces $=71$ BBNGL $(\mathrm{R} 2=$ $0.98)$ VSD for 141 provinces = 163 BBNGLVSD for 141 provinces plus Reserve Growth $(56 \%)=$ 254BBNGL 
International Journal of Global Energy Issues. 35 (6): 2012. http://dx.doi.org/10.1504/IJGEI.2012.051730. Copyright (C2012 Inderscience Enterprises Ltd.

Figure 2 Map showing 141 FSU provinces. Provinces shaded with horizontal stripes were previously assessed by USGS (2000)

Table 1 Province names, codes and oil endowments as assessed by USGS (2000)

\begin{tabular}{|c|c|c|}
\hline Province Name & Province Code & $\begin{array}{l}\text { Oil Endowment } \\
\text { (BBOE) }\end{array}$ \\
\hline TOTAL & & 380 \\
\hline West Siberian Basin & 1174 & 195.148 \\
\hline Volga-Ural Region & 1015 & 66.486 \\
\hline North Caspian Basin & 1016 & 34.129 \\
\hline $\begin{array}{l}\text { South Caspian } \\
\text { Basin }\end{array}$ & 1112 & 33.164 \\
\hline $\begin{array}{l}\text { Timan-Pechora } \\
\text { Basin }\end{array}$ & 1008 & 18.852 \\
\hline $\begin{array}{l}\text { Middle Caspian } \\
\text { Basin }\end{array}$ & 1109 & 14.439 \\
\hline $\begin{array}{l}\text { North Sakhalin } \\
\text { Basin }\end{array}$ & 1322 & 4.764 \\
\hline North Ustyurt Basin & 1150 & 3.320 \\
\hline Nepa-Botuoba Arch & 1210 & 3.214 \\
\hline $\begin{array}{l}\text { Dnieper-Donets } \\
\text { Basin }\end{array}$ & 1009 & 2.709 \\
\hline Baykit Arch & 1207 & 1.247 \\
\hline Amu-Darya Basin & 1154 & 1.036 \\
\hline Azov-Kuban Basin & 1108 & 0.940 \\
\hline $\begin{array}{l}\text { Angara-Lena } \\
\text { Terrace }\end{array}$ & 1209 & 0.242 \\
\hline South Barents Basin & 1050 & 0.219 \\
\hline Cis-Patom Foredeep & 1211 & 0.161 \\
\hline North Barents Basin & 1060 & 0.135 \\
\hline Ludlov Saddle & 1059 & 0.039 \\
\hline
\end{tabular}


International Journal of Global Energy Issues. 35 (6): 2012. http://dx.doi.org/10.1504/IJGEl.2012.051730.

Copyright (C2012 Inderscience Enterprises Ltd.

\begin{tabular}{|c|c|c|c|}
\hline & Province Name & Province Code & $\begin{array}{l}\text { Oil Endowment } \\
\text { (BBOE) }\end{array}$ \\
\hline & \multicolumn{2}{|l|}{ TOTAL } & 380 \\
\hline 1 & West Siberian Basin & 1174 & 195.148 \\
\hline 2 & Volga-Ural Region & 1015 & 66.486 \\
\hline 3 & North Caspian Basin & 1016 & 34.129 \\
\hline 4 & $\begin{array}{l}\text { South Caspian } \\
\text { Basin }\end{array}$ & 1112 & 33.164 \\
\hline 5 & $\begin{array}{l}\text { Timan-Pechora } \\
\text { Basin }\end{array}$ & 1008 & 18.852 \\
\hline 6 & $\begin{array}{l}\text { Middle Caspian } \\
\text { Basin }\end{array}$ & 1109 & 14.439 \\
\hline 7 & $\begin{array}{l}\text { North Sakhalin } \\
\text { Basin }\end{array}$ & 1322 & 4.764 \\
\hline 8 & North Ustyurt Basin & 1150 & 3.320 \\
\hline 9 & Nepa-Botuoba Arch & 1210 & 3.214 \\
\hline 10 & $\begin{array}{l}\text { Dnieper-Donets } \\
\text { Basin }\end{array}$ & 1009 & 2.709 \\
\hline 11 & Baykit Arch & 1207 & 1.247 \\
\hline 12 & Amu-Darya Basin & 1154 & 1.036 \\
\hline 13 & Azov-Kuban Basin & 1108 & 0.940 \\
\hline 14 & $\begin{array}{l}\text { Angara-Lena } \\
\text { Terrace }\end{array}$ & 1209 & 0.242 \\
\hline 15 & South Barents Basin & 1050 & 0.219 \\
\hline 16 & Cis-Patom Foredeep & 1211 & 0.161 \\
\hline 17 & North Barents Basin & 1060 & 0.135 \\
\hline 18 & Ludlov Saddle & 1059 & 0.039 \\
\hline & Province Name & Province Code & $\begin{array}{l}\text { Gas Endowment } \\
\text { (TCFG) }\end{array}$ \\
\hline & TOTAL & & 3,716 \\
\hline 1 & West Siberian Basin & 1174 & $1,912.983$ \\
\hline 2 & Amu-Darya Basin & 1154 & 393.993 \\
\hline 3 & North Caspian Basin & 1016 & 275.957 \\
\hline 4 & South Barents Basin & 1050 & 230.877 \\
\hline 5 & South Caspian Basin & 1112 & 209.304 \\
\hline 6 & Volga-Ural Region & 1015 & 103.108 \\
\hline 7 & Timan-Pechora Basin & 1008 & 88.714 \\
\hline & Province Name & Province Code & (BBOE) \\
\hline & TOTAL & & 380 \\
\hline 1 & West Siberian Basin & 1174 & 195.148 \\
\hline 2 & Volga-Ural Region & 1015 & 66.486 \\
\hline 3 & North Caspian Basin & 1016 & 34.129 \\
\hline 4 & $\begin{array}{l}\text { South Caspian } \\
\text { Basin }\end{array}$ & 1112 & 33.164 \\
\hline 5 & $\begin{array}{l}\text { Timan-Pechora } \\
\text { Basin }\end{array}$ & 1008 & 18.852 \\
\hline 6 & $\begin{array}{l}\text { Middle Caspian } \\
\text { Basin }\end{array}$ & 1109 & 14.439 \\
\hline 7 & $\begin{array}{l}\text { North Sakhalin } \\
\text { Basin }\end{array}$ & 1322 & 4.764 \\
\hline 8 & North Ustyurt Basin & 1150 & 3.320 \\
\hline 9 & Nepa-Botuoba Arch & 1210 & 3.214 \\
\hline 10 & $\begin{array}{l}\text { Dnieper-Donets } \\
\text { Basin }\end{array}$ & 1009 & 2.709 \\
\hline 11 & Baykit Arch & 1207 & 1.247 \\
\hline 12 & Amu-Darya Basin & 1154 & 1.036 \\
\hline 13 & Azov-Kuban Basin & 1108 & 0.940 \\
\hline 14 & $\begin{array}{l}\text { Angara-Lena } \\
\text { Terrace }\end{array}$ & 1209 & 0.242 \\
\hline 15 & South Barents Basin & 1050 & 0.219 \\
\hline 16 & Cis-Patom Foredeep & 1211 & 0.161 \\
\hline
\end{tabular}




\section{Production costs}

Data collected for conventional oil and gas in FSU shows a wide range of operating and capital costs (Aguilera et al., 2009). In 2010, production costs for conventional oil ranged from 5.00 to $30.00 \mathrm{USD} / \mathrm{BOE}$, with the majority costing around 14.00 USD/BOE. For the purpose of supply cost curve estimation, NGL quantities are included with oil and thus the oil definition hereafter includes NGL. The gas production costs ranged from 0.35 to 4.00 USD per thousand cubic feet (MCF), with the majority costing around 1.40 USD/MCF. The cost figures are composed of capital and operating costs, including a return on capital, but do not include taxes and royalties. Capital costs are mainly reflective of expenditures on development drilling, processing equipment, production facilities, pipelines and abandonment. Operating costs include mainly field operating costs and transportation costs. External costs, such as those associated with global warming, are not considered, largely because there is no consensus on what these costs are. It should be noted that production costs are not constant, but change over time to a significant degree. Currently, we are in a historical phase of high costs due to tight market conditions, frontier developments, shortages in the service and equipment sectors, and geopolitical factors. While some of these increases may be cyclical, reflecting the general boom in mineral production over recent years, others may be permanent. Ten years ago, the situation was different with prices and costs at much lower levels. Although the 2010 cost estimates in this study are static, they are meant to reflect current conditions (excluding regulatory and fiscal determinants). It is assumed that today's relatively high costs are a product of increased demand and declining production from existing fields. However, the costs have still been mitigated somewhat by advances in enhanced recovery, 
extensions of known reservoirs, and improved reservoir characterization. In section 6, an attempt is made to address possible cost evolution by presenting estimates for 2030 .

Some of the lower present-day costs refer to relatively shallow and favorable production conditions. The higher costs generally correspond to deep offshore production. Oil and gas production costs are influenced by factors such as geological conditions, depth of accumulations, regulatory environments, and project lengths (Adelman, 1993). Offshore capital cost increases at greater depths are mainly due to the higher cost of platform drilling, the cost of new technology to cope with depressurization of reservoirs, and the cost of pipeline transportation. However, significant cost savings have been achieved over the past decades on account of improved operating methods.

Longer term projections of oil and gas production costs will have to account for the cost-reducing effects of improved technology versus the cost-increasing effects of depletion. As fields at shallow depths are likely to be exploited first, there will be a gradual shift towards deeper drilling, including offshore, as well as a shift towards unconventional sources. This will require increased investment costs for new wells and higher operating expenditures due to additional costs for enhanced recovery. In the absence of advanced innovation, these factors are likely to drive up long run production costs. Though the past is not always an indication of the future, history suggests that producers will develop the technologies needed to offset the cost-increasing effects of deeper and more remote petroleum resources. 


\section{Resource categories}

Although several organizations publish estimates of oil and gas reserves and resources, it is difficult to categorize these definitions under a consistent classification system. The respective organizations tend to report their quantities using different terms, concepts, and boundaries. Attempts to create universal resource classification systems have been undertaken by SPE/WPC/AAPG/SPEE (2007) and UNFC (2009).

In the present study, oil and gas volumes are distinguished according to five production cost categories. The first category, CI, represents favorable production conditions such as shallow accumulations with high hydrocarbon content. The standard definition of Proved Reserves (P90; 1P) falls under CI. This category often serves as a public policy tool for many economic, political, technical, and environmental considerations. However, the proved reserve definition is limiting since it only represents quantities that are recoverable under existing market and technological conditions. Its use for long term investment decisions or policy analyses is thus restricted. Historically, proved reserves have increased over time despite increased production.

The second category, CII, respresents quantities that may be currently undiscovered but have a reasonable probability of being found according to geological and engineering data. Probable Reserves (P50; 2P) belong to CII. In time, these volumes will presumably come online as exploration and production efforts expand. As CI oil and gas quantities are exhausted, CII will replace them and move into the CI category themselves. 
Volumes that fall under the third category, CIII, are of a more optimistic and speculative nature in terms of geological information and economic feasibility. Possible Reserves (P10; 3P) fall under CIII. Over the medium to long term, as the CI and CII categories begin to dwindle, market and technological conditions should shift the CIII volumes into the $\mathrm{CII}$ and $\mathrm{CI}$ categories.

Categories CI to CIII represent conventional oil and gas that can be delineated with current geological techniques. The main characteristic of these categories is the uncertainty associated with their eventual discovery. The fourth and fifth categories encompass increasing uncertainty with respect to economic, geological, technical, and environmental factors.

The possibilities of enhanced oil and gas recovery is classified as CIV, however, may also apply to CI - CIII. Presently, oil recovery factors average around $35 \%$, and gas about $70 \%$, with primary and secondary production techniques. Additions to reserves due to increased recovery factors from tertiary production (e.g. steam injection; extensive hydraulic fracturing) are classified under the CIV category.

Oil and gas that cannot be produced with traditional or conventional methods because of technical and economic limitations fall under the fifth category, CV. Since this study does not consider unconventional sources such as heavy oil, oil sands, oil shale, tight gas sands, shale gas, coalbed methane, or gas hydrates, only quantities located in deep offshore reservoirs can be assigned to CV. These resources may be considered "unconventional" due to the novelty of deep sea drilling, even though the hydrocarbon itself is geologically conventional. 


\section{Supply cost curves}

In this study, supply cost curves are a function of remaining oil and gas volumes, production costs, and technological change. The latter is often associated with production cost reductions, though it is important to note that the concept of cost reduction normally results from either productivity improvements (i.e. the same amount of output with less inputs) and/or input cost reductions. For simplicity, terms such as technological change/improvement, productivity gains, and production cost reductions are used interchangeably in this paper and refer to advances in exploration and extraction methods that lead to lower capital and operating expenses.

Table 4 shows the oil production costs per BOE in 2010 USD, the assumed annual rates of technological improvement per production cost category, and the projected production costs for 2030 . There are five assumed cost categories with a lower and upper bound assigned to each category.

Table 4 Conventional oil production costs for 2010 and 2030 in USD/BOE Production costs (2010)Technology

Production costs (2030)Cost Lower Bound Upper Boundchange Lower Bound Upper BoundCategory(USD/BOE)(USD/BOE)in \%/yr(USD/BOE)(USD/BOE) Oil and NGLCI5.008.501.5\%3.706.30CII8.5014.001.0\%6.9511.45CIII14.0019.001.0\%11.4515.55CIV19.0025.000.5\%17.20 22.60CV25.0030.000.5\%22.6027.15 
The rates of technological improvement, ranging from $0.5 \%$ to $1.5 \%$ per year, reflect the well observed fact that advancement is greater under favorable production conditions. In the highest cost category $(\mathrm{CV})$, for example, compounded technological advancement of $0.5 \%$ per year until 2030 reduces the upper bound from 30.00 to $27.15 \mathrm{USD} / \mathrm{BOE}$. Annual productivity gains in the upstream sector have historically been observed at an average of about 1\% (Rogner, 1998). However, periods of two-digit growth, which usually occur in the short run, have often been followed by zero or negative increases, making productivity estimates highly uncertain (Adelman, 1995). Thus, the projected rates shown in Table 4 may prove to be pessimistic or optimistic. As stated by Adelman (1993, p. 81), "the most important variable in the long run is the least predictable: technical progress both in supply and in utilization."

Table 5 presents 2010 and 2030 production costs in USD per MCF, as well as technological improvement rates, for natural gas. In this case, technological advancement ranges from $1 \%$ to $1.5 \%$ per year. The upper bound of the fifth cost category, CV, has decreased from 4.00 USD/MCF in 2010 to 3.25 USD/MCF in 2030, assuming compounded technological change of $1 \%$ per year.

Table 5 Conventional gas production costs for 2010 and 2030 in USD/MCF

Production costs (2010)Technology Production costs (2030)Cost Lower Bound Upper Boundchange Lower Bound Upper BoundCategory(USD/MCF)(USD/MCF)in $\% / \mathrm{yr}(\mathrm{USD} / \mathrm{MCF})(\mathrm{USD} / \mathrm{MCF})$ Natural GasCI0.350.951.5\%0.250.70CII0.951.401.5\%0.701.05CIII1.402.201.5\%1.051.65CIV2.203.001.0\%1. 802.45CV3.004.001.0\%2.453.25 
Applying the assumed cost ranges per category to the oil and gas future volumes of FSU in a fixed proportion leads to supply cost curves for the region. Based on Aguilera et al. (2009), the distribution of oil across categories is assumed to be 5\% (CI), 40\% (CII), 35\% (CIII), 10\% (CIV), and 10\% (CV). The distribution of gas across categories is assumed to be $30 \%$ (CI), $40 \%$ (CII), $15 \%$ (CIII), $10 \%$ (CIV), and 5\% (CV).

Figure 3 shows two oil supply curves - one for the future volumes based on performance, productivity and costs associated with 2010 technology and one for the future volumes, performance and production technology expected by 2030 . The volumes in 2030 exclude any replenishment from the oil resource base potentially made possible by technological change and different market conditions but reflect the oil produced between 2010 and 2030 (assuming constant 2010 production levels derived from British Petroleum, 2011).

The potential future oil volume assessed for 2010 amounts to some 875 billion BOE (BBOE). This is calculated by subtracting FSU cumulative oil production until 2010 (174 BBOE; British Petroleum, 2011) from the VSD-calculated oil plus NGL endowment of 1049 BBOE. By 2030, the volume decreases to 775 BBOE due to a constant oil production rate of 5.0 BBOE per year (British Petroleum, 2011). 
International Journal of Global Energy Issues. 35 (6): 2012. http://dx.doi.org/10.1504/IJGEl.2012.051730.

Copyright @2012 Inderscience Enterprises Ltd.

Figure 32010 and 2030 supply cost curve for conventional oil and NGL in FSU

0.005.0010.0015.0020.0025.0030.0035.0001002003004005006007008009001000US\$ (2010) per BOEOil and NGL Future Volume (BBOE)2010 Technology2030 TechnologyAssessed by USGS(2000)Previouslyunssessed plus reservegrowth

Figure 4 follows the same procedure but presents supply cost curves for conventional gas. The total future volume in 2010 amounts to $6690 \mathrm{TCF}$. This is equal to the VSD-calculated endowment of 7507 TCF minus cumulative gas production until 2010 (817 TCF). A constant production rate of 27 TCF per year, based on 2010 production according to British Petroleum (2011), is used to calculate the volume in the 2030 supply curve $(6158 \mathrm{TCF})$. 
International Journal of Global Energy Issues. 35 (6): 2012. http://dx.doi.org/10.1504/IJGEl.2012.051730.

Copyright @2012 Inderscience Enterprises Ltd.

Figure 42010 and 2030 supply cost curve for conventional gas in FSU

0.000.501.001.502.002.503.003.504.004.5001000200030004000500060007000US\$ (2010) per MCFNatural Gas Future Volume (TCF)2010 Technology2030 TechnologyAssessedby USGS (2000)Previously unassessedplus reserve growth

\section{Conclusions}

The conventional oil, gas and NGL resource base in FSU is abundant and should last longer than many energy commentators assume. This is due to the significant volumes that exist in previously unassessed provinces, as well as the increases in volumes that occur as a result of reserve growth. Another finding is that FSU petroleum resources can be produced economically. The role of technological change over time diminishes production costs further in the year 2030. Figures 3 and 4 show oil and gas supply cost curves, respectively, based on present technology as well as 2030 technology. Although future production costs are lower due to improvements in the 
upstream sector, the available volumes have decreased due to annual production (using constant 2010 production levels). Thus, the 2030 curves exclude replenishment of oil and gas produced from 2010 until then. The replenishment would mostly take place due to increased geological information and improved recovery factors.

The results of this study imply that FSU petroleum can assist in meeting regional and global demand requirements. However, the existence of abundant resources alone will not guarantee security of supply. In order to develop the vast resources, appropriate public policies are necessary. For instance, the productivity gains that reduce production costs over time will not occur if investment does not take place on a timely basis. In the case of Russia, the IEA (2011) estimates necessary upstream oil investment of 738 billion USD and upstream gas investment of 733 billion USD from 2011-2035 to meet projected domestic and export requirements. Thus, policies must provide incentives for significant investment in technological development as well as environmental mitigation. It is also important that government intervention not create disincentives for the development of FSU petroleum resources. 
International Journal of Global Energy Issues. 35 (6): 2012. http://dx.doi.org/10.1504/IJGEl.2012.051730.

Copyright @2012 Inderscience Enterprises Ltd.

\section{References}

Adelman, M.A., Houghton, J.C., Kaufman, G.M., Zimmerman, M.B., 1983. Energy Resources in an uncertain future: coal, gas, oil, and uranium supply forecasting. Ballinger Publishing Company, Cambridge, Massachusetts.

Adelman, M.A., 1993. The Economics of Petroleum Supply. The MIT Press, Cambridge, Massachusetts.

Adelman, M.A., 1995. The Genie out of the Bottle: World Oil since 1970. The MIT Press, Cambridge, Massachusetts.

Aguilera, R.F., 2006. Assessing the Long Run Availability of Global Fossil Energy Resources. PhD Dissertation, Colorado School of Mines, Golden, Colorado.

Aguilera, R.F., 2011. Modeling petroleum resources in provinces of the Former Soviet Union. Energy Exploration and Exploitation, in press.

Aguilera, R.F., Eggert, R.G., Lagos, G., Tilton, J.E., 2009. Depletion and the future availability of petroleum resources. Energy Journal 30 (1), 141-174.

BGR, 2009. Energy resources: reserves, resources, availability. German Federal Institute for Geosciences and Natural Resources. Hannover, Germany.

British Petroleum, 2011. Statistical Review of World Energy 2011. British Petroleum, London.

Eckbo, P.L., Jacoby, H.D., Smith, J.L., 1978. Oil supply forecasting: a disaggregated process approach. Bell Journal of Economics 9, 218-235.

Gorst, I., 2010. Russian oil production growth under threat. Petroleum Economist 77(10), 12-13.

International Energy Agency, 2011. World Energy Outlook. Paris, France: Organization for Economic Cooperation and Development. 
International Journal of Global Energy Issues. 35 (6): 2012. http://dx.doi.org/10.1504/IJGEI.2012.051730.

Copyright @2012 Inderscience Enterprises Ltd.

Krichene, N., 2002. World crude oil and natural gas: a demand and supply model. Energy Economics 24, 557-576.

Lynch, M.C., 2005. Forecasting oil supply: theory and practice. The Quarterly Review of Economics and Finance 42, 373-389.

Palstev, S., 2011. Russia's natural gas export potential up to 2050. Supplementary Paper SP 3.1 Massachusetts Institute of Technology Study on the Future of Natural Gas.

http://web.mit.edu/mitei/research/studies/natural-gas-2011.shtml

Radetzki, M., 2012. Politics - not OPEC interventions - explain oil's extraordinary price history. Energy Policy 46, 382-385.

Rogner, H. H., 1998. An assessment of world hydrocarbon resources. International Institute for Applied Systems Analysis (IIASA) Publications, RR-98-6. Also, Annual Review of Energy and Environment 22: 217-262, 1997.

Sorrell, S., Speirs, J., Bentley, R., Brandt, A., Miller, R., 2010. Global oil depletion: a review of the evidence. Energy Policy 38, 5290-5295.

SPE/WPC/AAPG/SPEE, 2007. Petroleum Resources Management System (PRMS). Society of Petroleum Engineers/World Petroleum Council/American Association of Petroleum Geologists/Society of Petroleum Evaluation Engineers.

Walls, M.R., 2004. Combining decision analysis and portfolio management to improve project selection in the exploration and production firm. Journal of Petroleum Science and Engineering 44, 55-65.

Tilton, J.E., Skinner, B.J., 1987. The meaning of resources, in: McLaren, D.J., Skinner, B.J. (Eds.), Resources and World Development. John Wiley \& Sons, New York.

UNFC, 2009. United Nations Framework Classification for Fossil Energy and Mineral Reserves and Resources. UN Economic Commission for Europe, Geneva. 
International Journal of Global Energy Issues. 35 (6): 2012. http://dx.doi.org/10.1504/IJGEI.2012.051730. Copyright (C2012 Inderscience Enterprises Ltd.

USGS, 2000. United States Geological Survey World Petroleum Assessment. CD-ROM, Reston, Virginia.

Verma, M.K., 2000. The significance of field growth and the role of enhanced oil recovery. USGS Fact Sheet FS-115-00, Denver, Colorado. 